\title{
Efek Paparan Musik Klasik, Hard Rock dan Murottal Terhadap Pertumbuhan Vegetatif Tanaman Bayam Merah (Alternanthera amoena Voss)
}

\author{
Resti $^{1}$, Elvi Rusmiyanto PW ${ }^{1}$, Diah Wulandari Rousdy ${ }^{1}$ \\ ${ }^{1}$ Program Studi Biologi, Fakultas MIPA, Universitas Tanjungpura, Jl. Prof. Dr. H. Hadari , Pontianak \\ Email korespondensi : bioresti9@gmail.com
}

\begin{abstract}
Abstrak
This research was conducted to determine the effect of classical music, hard rock and murottal against to vegetative growing of red spinach plants. The research used a completely randomizes design with 4 treatments and 5 replicates. ANOVA result showed that music exposure had significant effect on plant growth. Murottal exposure gave optimal result on plant height $35,70 \mathrm{~cm}$, leaf area $43,40 \mathrm{~cm}^{2}$, root length $9,40 \mathrm{~cm}$, stomata porous length $23,00 \mu \mathrm{m}$, wet weigh $15,59 \mathrm{~g}$, and dry weight of the plant $11,25 \mathrm{~g}$. Exposure to hard rock music gives optimal results on the amount of leaf chlorophyll is worth 34,52 spad unit.
\end{abstract}

Keywords: Sound waves, music, red spinach, vegetative growth

\section{PENDAHULUAN}

Kebutuhan sayuran di Kalimantan Barat terus menerus meningkat, dikarenakan sayur menjadi kebutuhan sehari-hari. Menurut Badan Pusat Statistik Provinsi Kalimantan Barat tingkat produksi tanaman bayam pada tahun 2015 mencapai 4.650 ton. Tingkat produksi tersebut masih rendah dibandingkan dengan tanaman sayuran lainnya seperti kangkung yang memiliki nilai produksi hingga mencapai 6.905 ton.

Bayam merah (Alternanthera amoena Voss) merupakan salah satu varietas bayam cabut yang memiliki ciri khusus yaitu daun dan batang berwarna merah. Warna merah pada tanaman ini berasal dari kandungan pigmen antosianin. Antosianin berguna sebagai antioksidan untuk mencegah radikal bebas, selain itu pigmen ini dapat digunakan sebagai pewarna alami (Pebrianti et al., 2015; Hapsari, 2014)

Bayam merah memiliki kandungan nutrisi berupa vitamin $\mathrm{A}$ (beta-karoten), vitamin $\mathrm{C}$, riboflavin, asam amino thiamin dan niasin (Bandini \& Nurudin, 1999). Menurut Iriyani \& Pangesti (2014), bayam memiliki kandungan klorofil dan karotenoid lebih tinggi dibanding sayuran kangkung dan sawi. Tingginya kandungan klorofil menunjukkan tingginya nutrisi pada tanaman. Klorofil diketahui berperan sebagai antioksidan dalam tubuh yang dapat menyembuhkan penyakit anemia.

Pertumbuhan suatu tanaman bergantung pada jumlah nutrisi dan unsur hara yang diberikan serta faktor lingkungan yang mendukung. Rendahnya jumlah nutrisi dan unsur hara bagi tanaman menyebabkan pertumbuhan tanaman terganggu. Salah satu cara untuk meningkatkan pertumbuhan tanaman melalui pemanfaatan teknologi sonic bloom.

Aplikasi sonic bloom merupakan sebuah pengembangan ilmu pengetahuan dan teknologi di bidang pertanian yang memanfaatkan gelombang suara dengan frekuensi tinggi tanpa merusak lingkungan sekitar (Utami \& Agus, 2013).

Getaran bunyi dapat memacu pembukaan stomata. Menurut Kadarisman et al., (2011) pembukaan stomata terjadi apabila kedua sel penjaga bergetar akibat peningkatan tekanan karena pengaruh resonansi suara yang menyebabkan masuknya air ke dalam sel penjaga tersebut dan mampu meningkatkan tekanan osmotik. Berdasarkan penelitian Damayanti (2016), pemberian suara serangga (Dundubia manifera) memberikan pengaruh nyata terhadap pertumbuhan tanaman jahe.

Tumbuhan dapat merespon jenis musik yang berbeda-beda. Hal ini sesuai dengan penelitian yang dilakukan oleh Prasetyo (2014), paparan musik klasik meningkatkan daya berkecambah tanaman sawi hijau lebih baik dibanding paparan kebisingan. Berbeda dengan penelitian Utami et al., (2012) musik hard rock memberikan respon pertumbuhan yang baik pada tanaman cabai merah keriting.

Aplikasi sonic bloom ini telah banyak dilakukan dengan berbagai jenis musik maupun suara terhadap tanaman yang berbeda-beda. Akan tetapi efek paparan musik klasik, hard rock, maupun murottal 
terhadap tanaman bayam merah belum banyak diketahui sehingga penelitian ini perlu dilakukan untuk meningkatkan produksi tanaman bayam merah.

\section{BAHAN DAN METODE Waktu dan Tempat Penelitian}

Penelitian ini dilaksanakan pada bulan Desember 2017 sampai Februari 2018 di rumah kasa dan pengamatan pembukaan stomata dilakukan di Laboratorium Biologi Fakultas Matematika dan Ilmu Pengetahuan Alam Universitas Tanjungpura.

\begin{abstract}
Alat dan Bahan
Alat yang digunakan dalam penelitian ini adalah alat tulis, ayakan tanah, baskom, box MP3 player, chamber (kotak kedap suara), gelas penutup, gelas objek, hygrometer, klorofilmeter, meteran jahit, mikroskop, mikrometer okuler dan objektif, neraca analitic, oven, penggaris, polibag berdiameter 20 $\mathrm{cm}$ dengan tinggi $15 \mathrm{~cm}$, soil tester, sound level meter, sprayer. Bahan yang digunakan adalah air keran, benih bayam merah varietas Mira (cap Panah Merah), tanah gambut dari lahan perkebunan Siantan dan pupuk kotoran ayam.
\end{abstract}

\section{Rancangan Penelitian}

Penelitian ini menggunakan Rancangan Acak Lengkap dengan empat perlakuan yaitu $\left(\mathrm{M}_{0}\right)$ perlakuan kontrol tanpa perlakuan, $\left(\mathrm{M}_{1}\right)$ musik klasik "Maid with the flaxen hair dari Richard Stoltzam, $\left(\mathrm{M}_{2}\right)$ musik hard rock "Afterlife dari Avenged Sevenfold", $\left(\mathrm{M}_{3}\right)$ murottal "Al-Insan dari Ust.Hanan Attaki". Setiap perlakuan terdiri dari lima pengulangan sehingga diperoleh dari 20 unit percobaan.

\section{Prosedur Kerja}

\section{Persiapan Media Tanam}

Media tanam yang digunakan terdiri tanah gambut dan pupuk kotoran ayam dengan perbandingan 3:1. Tanah gambut yang digunakan dikeringanginkan dan diayak terlebih dahulu. Kemudian media tanam tersebut dimasukkan kedalam polibag dan dibiarkan selama 3 hari sebelum penanaman.

\section{Penanaman}

Benih bayam merah direndam terlebih dahulu dengan air hangat selama 5 menit. Benih yang dipilih adalah benih yang tenggelam. Penanaman dilakukan dengan cara menanam langsung benih bayam di media tanam. Setiap polybag terdapat 3 tanaman. Benih bayam yang sudah tumbuh akan diseleksi dan disisakan satu tanaman dalam polybag sebagai sampel penelitian hingga berumur 40 HST (Hari Setelah Tanam).

\section{Pemberian Perlakuan Musik}

Pelaksanaan penelitian dilakukan dengan pemberian musik selama 3 jam setiap harinya mulai pukul 07.00-10.00 WIB (Susanti et al. 2013). Pemberian musik dimulai dari persemaian hingga tanaman berumur 40 HST.

Benih bayam merah pada media tanam disimpan didalam chamber yang didalamnya terdapat speaker aktif. Jenis musik yang digunakan adalah musik klasik "Maid with the flaxen hair dari Richard Stoltzam", hard rock "Afterlife" dari Avenged Sevenfold", dan murottal "Al-Insan dari Ust.Hanan Attaki" dan sebagai pembanding disimpan didalam chamber tanpa musik (kontrol). Level bunyi yang digunakan berkisar antara 70-75 dB. Analisis frekuensi menggunakan software Adobe Audition 3.0 (Adobe Inc.,USA) didapat musik klasik mempunyai rentang frekuensi $143-383 \mathrm{~Hz}$, musik hard rock rentang frekuensi $120-192 \mathrm{~Hz}$ dan murottal mempunyai rentang frekuensi $165-423 \mathrm{~Hz}$.

\section{Pemeliharaan}

Pemeliharaan tanaman terdiri dari penyiangan, penyulaman, dan penyiraman. Penyiangan dilakukan dengan mencabut gulma yang ada pada tanaman. Proses penyulaman adalah proses menggantitanaman yang mati dengan tanaman baru paling lama dilakukan 7 hari setelah tanam. Penyiraman dilakukan setiap hari pukul 06.0007.00 WIB dan sore hari pukul 16.00-17.00 WIB

\section{Variabel Pengamatan}

Parameter pertumbuhan tanaman yang diamati terdiri dari tinggi tanaman $(\mathrm{cm})$, luas daun $\left(\mathrm{cm}^{2}\right)$, berat basah dan berat kering tanaman (g), panjang akar $(\mathrm{cm})$, bukaan stomata $(\mu \mathrm{m})$, klorofil (spad unit). Parameter lingkungan yang diukur pada penelitian ini yaitu suhu udara, kelembaban tanah, kelembaban udara dan $\mathrm{pH}$ tanah. Pengukuran parameter lingkungan dilakukan setiap hari yakni pada pagi (07.00-08.00 WIB), siang (12.00-13.00 WIB) dan sore hari (17.00-18.00).

\section{Analisis Data \\ Data-data yang dihasilkan dianalisis menggunakan Analisis of Varians (ANOVA) satu jalur untuk mengetahui pengaruh perbedaan jenis musik terhadap pertumbuhan vegetatif bayam merah. Data dianalisis menggunakan program SPSS 18. Perbedaan antar perlakuan dianalisis lanjut menggunakan Duncan's Multi Range Test (DMRT) taraf kepercayaan $95 \%(\mathrm{P}<0,05)$.}




\section{HASIL DAN PEMBAHASAN \\ Hasil}

Tinggi Tanaman, Luas Daun dan Panjang Akar

Berdasarkan hasil analisis ANOVA menunjukkan bahwa paparan musik berpengaruh nyata terhadap tinggi tanaman $\left(\mathrm{F}_{3,16}=18,065, p=0,000\right)$, luas daun $\left(\mathrm{F}_{3,16}=18,284, \quad p=0,000\right)$, dan panjang akar $\left(\mathrm{F}_{3,16}=4,203, p=0,023\right)$. Rerata nilai paling tinggi terdapat pada perlakuan M3 yaitu tinggi tanaman senilai $35,70 \mathrm{~cm}$, luas daun senilai $43,40 \mathrm{~cm}^{2}$ dan panjang akar senilai $9,40 \mathrm{~cm}$ (Tabel 1)

Tabel 1 Pengaruh Paparan Jenis Musik Terhadap Tinggi Tanaman, Luas Daun dan Panjang Akar

\begin{tabular}{cccc}
\hline Perlakuan & $\begin{array}{c}\text { Tinggi } \\
\text { Tanaman } \\
(\mathrm{cm})\end{array}$ & $\begin{array}{c}\text { Luas Daun } \\
\left(\mathrm{cm}^{2}\right)\end{array}$ & $\begin{array}{c}\text { Panjang } \\
\text { Akar }(\mathrm{cm})\end{array}$ \\
\hline M0 & $15,96 \pm 4,09^{\mathrm{a}}$ & $20,00 \pm 6,48^{\mathrm{a}}$ & $6,80 \pm 1,30^{\mathrm{a}}$ \\
M1 & $28,94 \pm 2,03^{\mathrm{b}}$ & $31,00 \pm 3,46^{\mathrm{b}}$ & $8,10 \pm 1,14^{\mathrm{ab}}$ \\
M2 & $24,38 \pm 3,80^{\mathrm{b}}$ & $23,40 \pm 2,07^{\mathrm{a}}$ & $7,00 \pm 1,22^{\mathrm{a}}$ \\
M3 & $35,70 \pm 6,38^{\mathrm{c}}$ & $43,40 \pm 7,67^{\mathrm{c}}$ & $9,40 \pm 1,52^{\mathrm{b}}$ \\
\hline
\end{tabular}

Ket : Angka yang diikuti oleh huruf yang sama menunjukkan hasil tidak berbeda nyata menurut uji Duncan pada taraf kepercayaan 95\%

M0=Kontrol; M1=Klasik; M2=Hard rock; M3=Murottal

Hasil analisis Duncan menunjukkan rerata tinggi tanaman pada semua perlakuan berbeda nyata dengan M0. Nilai rerata tinggi tanaman pada perlakuan M3 berbeda nyata dengan M0, M1 dan M2 $(\mathrm{P}<0,05)$ sedangkan nilai $\mathrm{M} 1$ tidak berbeda nyata dengan M2. Nilai rerata tinggi tanaman paling tinggi terdapat pada perlakuan M3 yaitu senilai $35,70 \mathrm{~cm}$.

Rerata luas daun pada perlakuan M3 berbeda nyata dengan M0, M1, dan M2 ( $<00,05)$ sedangkan nilai M0 tidak berbeda nyata dengan M2. Nilai rerata luas daun paling tinggi terdapat pada perlakuan M3 yaitu senilai $43,40 \mathrm{~cm}^{2}$.

Hasil uji parameter panjang akar pada perlakuan M0 tidak berbeda nyata dengan M1 dan M2, sedangkan pada perlakuan M3 tidak berbeda nyata dengan M1. Nilai rerata panjang akar paling tinggi terdapat pada perlakuan M3 yaitu senilai 9,40 cm (Tabel 1).

\section{Jumlah Klorofil Daun (Spad Unit)}

Berdasarkan hasil analisis Anova jumlah klorofil daun pada tamanan bayam merah diketahui bahwa paparan musik berpengaruh nyata terhadap jumlah klorofil $\left(\left(\mathrm{F}_{3,16}=6,947, p=0,003\right)\right.$ (Tabel 2).

Hasil uji parameter kandungan klorofil menunjukkan bahwa rerata pada perlakuan M2 berbeda nyata terhadap M0, M1, dan M3 $(\mathrm{P}<0,05)$. Perlakuan M0 menunjukkan hasil yang tidak berbeda nyata dengan M1 dan M3. Kandungan klorofil tertinggi pada perlakuan M2 yaitu senilai 34,52 spad unit.

Tabel 2 Pengaruh Paparan Jenis Musik Terhadap Jumlah Klorofil Daun Bayam Merah

\begin{tabular}{cc}
\hline Perlakuan & Rerata (spad unit) \\
\hline M0 & $25,80 \pm 1,45^{\mathrm{a}}$ \\
M1 & $30,14 \pm 3,70^{\mathrm{a}}$ \\
M2 & $34,52 \pm 4,73^{\mathrm{b}}$ \\
M3 & $28,02 \pm 1,19^{\mathrm{a}}$
\end{tabular}

Ket : Angka yang diikuti oleh huruf yang sama menunjukkan hasil tidak berbeda nyata menurut uji Duncan pada taraf kepercayaan $95 \%$

M0=Kontrol; M1=Klasik; M2=Hard rock; M3=Murottal

\section{Panjang dan Lebar Porus Stomata}

Berdasarkan hasil analisis menunjukkan bahwa pemberian perlakuan musik berpengaruh nyata terhadap panjang porus stomata $\left(\mathrm{F}_{3,16}=16,815\right.$, $p=0,000)$ dan tidak berpengaruh nyata terhadap lebar porus stomata $\left(\mathrm{F}_{3,16}=1,407, p=0,027\right)$ (Tabel $3)$.

Tabel 3 Pengaruh Paparan Jenis Musik Terhadap Panjang dan Lebar Stomata Daun Bayam Merah

\begin{tabular}{lcc}
\hline Perlakuan & $\begin{array}{c}\text { Panjang Porus } \\
(\mu \mathrm{m})\end{array}$ & $\begin{array}{c}\text { Lebar Porus } \\
(\mu \mathrm{m})\end{array}$ \\
\hline M0 & $19,00 \pm 1,37^{\mathrm{ab}}$ & $8,00 \pm 1,12^{\mathrm{a}}$ \\
M1 & $20,50 \pm 1,12^{\mathrm{b}}$ & $8,00 \pm 1,12^{\mathrm{a}}$ \\
M2 & $18,00 \pm 1,12^{\mathrm{a}}$ & $7,00 \pm 1,12^{\mathrm{a}}$ \\
M3 & $23,00 \pm 1,12^{\mathrm{c}}$ & $8,50 \pm 1,37^{\mathrm{a}}$ \\
\hline Ket : Angka yang diikuti oleh huruf yang sama & hen \\
menunjukkan hasil tidak berbeda nyata menurut \\
uji Duncan pada taraf kepercayaan 95\% \\
M0=Kontrol; M1=Klasik; M2=Hard rock; \\
M3=Murottal
\end{tabular}

Hasil uji Duncan menunjukkan rerata panjang porus stomata pada perlakuan M3 berbeda nyata dengan M0, M1 dan M2 $(\mathrm{P}<0,05)$. Rerata pada perlakuan M0 tidak berbeda nyata dengan M1 dan M2. Nilai rerata panjang porus paling tinggi terdapat pada perlakuan M3 yaitu senilai 23,00 $\mu \mathrm{m}$. Rerata pemberian paparan musik terhadap lebar porus stomata pada setiap perlakuan tidak berbeda nyata dengan M0 (Tabel 3).

\section{Berat Basah dan Berat Kering Tanaman}

Berdasarkan hasil Anova menunjukkan bahwa paparan musik berpengaruh nyata terhadap berat basah $\left(\mathrm{F}_{3,16}=9,914, \quad p=0,001\right)$ dan berat kering tanaman $\left(\mathrm{F}_{3,16}=14,525, p=0,000\right)$. Nilai rerata berat 
basah dan berat kering tertinggi yaitu pada perlakuan M3 (Tabel 4)

Tabel 4 Rerata Berat Basah dan Berat Kering Bayam Merah

\begin{tabular}{ccc}
\hline Perlakuan & $\begin{array}{c}\text { Berat Basah } \\
\text { Tanaman }(\mathrm{g})\end{array}$ & $\begin{array}{c}\text { Berat Kering } \\
\text { Tanaman }(\mathrm{g})\end{array}$ \\
\hline M0 & $4,69 \pm 3,23^{\mathrm{a}}$ & $1,09 \pm 1,37^{\mathrm{a}}$ \\
M1 & $10,32 \pm 1,59^{\mathrm{b}}$ & $5,44 \pm 1,51^{\mathrm{b}}$ \\
M2 & $7,44 \pm 1,23^{\mathrm{ab}}$ & $4,76 \pm 1,34^{\mathrm{b}}$ \\
M3 & $15,59 \pm 5,41^{\mathrm{c}}$ & $11,25 \pm 4,28^{\mathrm{c}}$ \\
\hline
\end{tabular}

Ket : Angka yang diikuti oleh huruf yang sama menunjukkan hasil tidak berbeda nyata menurut uji Duncan pada taraf kepercayaan $95 \%$

M0=Kontrol; M1=Klasik; M2=Hard rock; M3=Murottal

Rerata berat basah tanaman pada perlakuan M3 berbeda nyata terhadap M0, M1 dan M2 $(\mathrm{P}<0,05)$. Nilai rerata M0 tidak berbeda nyata terhadap M2 sedangkan perlakuan M1 tidak berbeda nyata dengan M2. Nilai rerata tertinggi terhadap berat basah tanaman terdapat pada perlakuan M3 yaitu senilai 15,59 g. Hasil uji parameter rerata berat kering tanaman pada M0 berbeda nyata dengan M1, M2 dan M3. Nilai rerata tertinggi berat kering tanaman terdapat pada perlakuan M3 yaitu senilai 11,25 g (Tabel 4).

\section{PEMBAHASAN}

Teknologi sonic bloom merupakan pengembangan ilmu pengetahuan di bidang pertanian yang memanfaatkan gelombang suara untuk meningkatkan pertumbuhan tanaman. Teknologi ini diterapkan sebagai inovasi teknologi dalam budidaya tanaman bayam merah dapat bekerja dengan baik. Tanaman bayam merah yang diperlakukan dengan sonic bloom memperlihatkan pertumbuhan yang lebih baik daripada tanaman kontrol.

Hasil penelitian dapat diketahui bahwa pemberian paparan musik pada tanaman bayam merah berpengaruh nyata terhadap parameter tinggi tanaman, luas daun, panjang akar, panjang porus stomata, serta berat basah dan berat kering (Tabel 1, 2, 3 dan 4). Hal ini menandakan bahwa paparan musik dapat memacu pertumbuhan tanaman bayam merah. Menurut Chivukula \& Shivaraman (2014) paparan musik dapat mempengaruhi metabolisme pada tanaman serta mengaktifkan enzim.

Pengaruh paparan musik dari hasil penelitian ini sangat berpengaruh terhadap tinggi tanaman. Hasil tinggi tanaman menunjukkan bahwa paparan murottal memberikan hasil yang terbaik pada nilai rerata tinggi tanaman bayam merah (Tabel 1). Paparan murottal diduga dapat mengakibatkan meristem apikal pada bagian pucuk tanaman aktif membelah sehingga tanaman akan bertambah tinggi. Paparan musik klasik dan hard rock juga dapat meningkatkan pertambahan tinggi tanaman dibanding kontrol. Menurut Prasetyo (2014) paparan musik klasik memberikan pertambahan tinggi tanaman sawi menjadi lebih baik. Begitu halnya dengan penelitian Utami et al., (2012) dimana pertambahan tinggi tanaman terbaik pada paparan musik hard rock terhadap tanaman cabe keriting. Menurut Damayanti (2016) gelombang suara dapat meningkatkan penyerapan gas $\mathrm{CO}_{2}$ untuk proses fotosintesis. Hasil fotosintesis ini dimanfaatkan oleh tanaman untuk aktivitas pemanjangan dan pembelahan sel pada bagian meristem apikal sehingga tinggi tanaman dapat meningkat.

Perlakuan paparan musik memberikan pengaruh yang nyata terhadap peningkatan luas daun dan panjang akar dibanding dengan tanaman kontrol (Tabel 1). Hasil luas daun dan panjang akar menunjukkan bahwa paparan murottal memberikan hasil yang terbaik. Hal ini dikarenakan getarangetaran atau gelombang-gelombang yang diakibatkan oleh murottal diduga mampu mengubah aktivitas metabolisme sel sehingga memungkinkan sel melakukan transfer senyawa seperti asam amino dan ATP.

Menurut Hassanien et al., (2013) gelombang suara dapat mempercepat gerakan protoplasma dalam sel dan mentransfer energi kedalam sel dan sitoplasma. Stimulasi gelombang suara dapat meningkatkan aktivitas enzim $\mathrm{H}^{+}$-ATPase yang terdapat pada membran plasma. Enzim $\mathrm{H}^{+}$-ATPase merupakan protein enzim utama dari membran plasma yang bertanggung jawab dalam pembentukan potensial membran sel pada tanaman yang memiliki peran penting dalam proses pertumbuhan dan perkembangan tanaman.

Pemberian perlakuan paparan musik memberikan pengaruh nyata terhadap jumlah klorofil daun. Berdasarkan hasil statistik, paparan musik hard rock memberikan jumlah klorofil yang terbaik (Tabel 2). Paparan musik hard rock dianggap suatu tekanan bagi tanaman. Musik hard rock memiliki beat yang kuat dan keras dengan rentang frekuensi yang pendek (120-129 $\mathrm{Hz})$ sehingga dapat memperlambat pertumbuhan tanaman. Menurut Chowdhury \& Gupta (2012) menyatakan bahwa semakin rendah frekuensi suara yang diberikan maka akan memperlambat pertumbuhan tanaman. Berdasarkan hasil penelitian terhadap tinggi tanaman, luas daun, panjang akar, berat basah dan 
berat kering tanaman yang terpapar musik hard rock menunjukkan bahwa pertumbuhan tanaman tidak berbeda nyata sama dengan tanaman kontrol. Akan tetapi, tanaman bayam merah dapat merespon dengan baik musik hard rock dengan meningkatkan jumlah klorofil.

Hasil pengamatan terhadap panjang porus stomata menunjukkan bahwa paparan musik memberikan pengaruh nyata dibanding tanaman kontrol. Hasil statistik menunjukkan bahwa paparan murottal memberikan hasil yang optimal terhadap rerata panjang porus stomata (Tabel 3). Berdasarkan penelitian Susanti (2013) tanaman sawi yang diberi paparan musik gamelan jawa dapat menyebabkan pembukaan stomata menjadi lebih luas. Penelitian Kadarisman et al., (2011) menyatakan bahwa tanaman kacang yang diberi paparan bunyi serangga dapat menstimulus terbukanya stomata menjadi lebih luas dibanding tanaman kontrol.

Pembukaan stomata lebih luas disebabkan oleh frekuensi suara tertentu yang dapat mengaktifkan gen-gen tertentu dalam sel sehingga mempengaruhi pertumbuhan sel dan ekspresi sel. Ekspresi sel adalah suatu proses dimana kode informasi dalam gen diubah menjadi protein yang dioperasikan didalam sel (Doorne, 2000). Oleh karena itu frekuensi atau gelombang suara murottal diduga dapat mengaktifkan gen tersebut. Frekuensi suara tertentu beresonansi dengan rongga stomata, sehingga meningkatkan penyerapan air. Gelombang suara yang berasal dari sumber suara menuju sitoplasma yang menyebabkan munculnya mikrogelembung. Selanjutnya mikro-gelembung ini akan beresonansi dengan suara dan mendorong dinding sel penjaga. Oleh karena itu tekanan turgor meningkat dan stomata terbuka. Gelombang suara dapat menyebar melalui cairan sitoplasma dan merangsang pergerakan molekul seperti proses difusi (Collins \& Fareman, 2000).

Berdasarkan hasil statistik terhadap nilai rerata lebar porus stomata pada penelitian ini yang diberi paparan musik selama 3 jam tidak memberikan pengaruh yang nyata terhadap tanaman kontrol. Menurut Pujiwati \& Djuhari (2014), semakin lama durasi paparan, semakin rendah lebar pembukaan stomata. Pada awal durasi paparan, pembukaan stomata menjadi lebih luas sehingga kenaikan tingkat transpirasi akan mengakibatkan penurunan kadar air dari sel penjaga, tekanan turgor menurun dan pembukaan stomata akan menyusut. Penutupan stomata ini adalah salah satu cara tanaman untuk mencegah kehilangan air sehingga dapat memperlambat transpirasi dan difusi $\mathrm{CO}_{2}$ dalam rongga substomata. Oleh karena itu, pada penelitian ini paparan musik selama 3 jam pada tanaman bayam tidak memberikan hasil yang optimal terhadap lebar porus stomata.

Pemberian paparan musik berpengaruh nyata terhadap parameter berat basah dan berat kering tanaman berpengaruh nyata terhadap tanaman kontrol. Berdasarkan uji ANOVA, paparan murottal memberikan hasil yang lebih optimal terhadap rerata berat basah dan berat kering tanaman bayam merah (Tabel 4). Paparan murottal dapat meningkatkan pertambahan sel pada primordial daun dan meristem pucuk apeks sehingga berat basah tanaman bayam merah meningkat. Bertambahnya jumlah sel secara tidak langsung akan menambah kadar air dan mengakibatkan bertambahnya berat basah tanaman. Menurut Lakitan (1993) penyusun sel tanaman adalah air sebanyak $90 \%$.

Musik dapat meningkatkan metabolisme tanaman, salah satunya dengan meningkatkan akumulasi fotosintat. Berat basah dan berat kering tanaman merupakan hasil akumulasi fotosintat berupa asam amino, lipid, protein dan polisakarida yang ditranslokasikan ke jaringan tanaman yang dipengaruhi oleh jumlah serapan air dan hara yang ada didalam tanah (Sitompul \& Guritno, 1995). Menurut Jumin (1991) unsur hara yang diserap oleh tanaman dari tanah akan sangat berpengaruh terhadap berat kering tanaman. Tersedianya hara dapat meningkatkan perkembangan organ-organ tanaman sehingga mampu berfotosintesis lebih optimal dan fotosintat yang tertimbun dapat meningkatkan bobot kering tanaman. Semakin bertambah jumlah sel maka berat kering tanaman juga semakin meningkat. Oleh sebab itu, berdasarkan penelitian ini, semakin tinggi rerata nilai berat kering tanaman maka pertumbuhan tanaman bayam semakin meningkat (Tabel 4).

\section{DAFTAR PUSTAKA}

Bandini, Y \& Nurudin, A, 1999, Bayam, Penebar Swadaya, Jakarta

Badan Pusat Statistik, 2015, Statistik Pertanian Tanaman Sayuran dan Buah-buahan, Provinsi Kalimantan Barat, Kalimantan Barat

Chowdhury, AR \& Gupta, A, 2012, Effect of Music on Plants - An Overview, International Journal of Integrative Sciences, Innovation and Technology (IJIIT), vol.4, no.6, hal. 30 34.

Chivukula, V \& Shivaraman R, 2014, Effect of Different Types of Music on Rosa Chinensis Plants, International Journal of Environmental Science and Development, vol. 5, no. 5 
Collins, ME \& Foreman, JEK, 2001, The Effect of Sound on the Growth of Plants, Canadian Acoustics, vo.2, hal. 3-8

Damayanti, 2016, Pengaruh Pemberian Suara Garengpung ( Dundubia manifera) dengan Intensitas Waktu Tertentu Terhadap Pertumbuhan Tanaman Jahe Merah (Zingiber officinale), Skripsi, Universitas Sanata Dharma, Yogyakarta

Doorne, Y, 2000, Influence of Variabel Sound Frequencies on the Growth and Developpement of Plants, Hogeschool Gent, Belgium

Hassanien, R, Hou, T, Li,Y \& Li, B, 2013, Advances in Effects of Sound Waves of Plants, Journal of integrative Agriculture, vol.13, no.2, hal. 335-348

Hapsari, ND, 2014, Kadar Glukosa dan Kalsium Yoghurt Biji Keluwih dengan Penambahan Jenis Pemanis dan Daun Bayam Merah (Alternanthera Amoena Voss) Sebagai Pewarna Alami, Naskah Publikasi, Universitas Muhammadiyah Surakarta, Surakarta

Iriyani, D \& Pangesti, N, 2014, Kandungan Klorofil, Karotenoid dan Vitamin C Beberapa Jenis Sayuran Daun pada Pertanian Periurban di Kota Surabaya, Jurnal Matematika, Sains, dan Teknologi, vol.5, no. 2, hal.84-90

Jumin, 1991, Ekologi Tanaman Suatu Pendekatan Fisiologi, Rajawali Press, Jakarta

Kadarisman, N, Agus, P \& Dadan, R, 2011, Rancang Bangun Audio Organic Growth System (Aogs) Melalui Spesifikasi Spektrum Bunyi Binatang Alamiah Sebagai Local Genius Untuk Peningkatan Kualitas Dan Produktivitas Tanaman Holtikultura, Prosiding Seminar Nasional Penelitian, Pendidikan dan Penerapan MIPA, Fakultas MIPA, Universitas Negeri Yogyakarta

Lakitan, B, 1993, Dasar-Dasar Fisiologi Tumbuhan, PT Raja Grafindo Persana, Jakarta
Pebrianti,C, Ainurrasyid \& Sri, LP, 2015, Uji Kadar Antosianin dan Hasil Enam Varietas Tanamn Bayam Merah (Alternanthera amoena Voss) pada Musim Hujan, Jurnal Produksi Tanaman, vol.3, no.1, hal.27-33

Prasetyo, J, 2014, Efek Paparan Musik dan Noise pada Karakteristik Morfologi dan Produktivitas Tanaman Sawi Hijau (Brassica juncea), Jurnal Keteknikan Pertanian, vol.2, no.1

Pujiwati, I \& Djuhari, 2014, The Pattern of Stomatal Opening through the Exposure of High-Frequency Sound Wave with the Diffrent Duration and Age of Soybeans (Glycine $\max (\mathrm{L}$.$) Merril), Agricultural$ Science, vol.2, hal.69-77

Sitompul \& Guritno, B, 1995, Analisis Pertumbuhan Tanaman Bayam, Gadjah Madha Universitas, Yogyakarta

Susanti, T, Ferdy, SR \& Adita, S, 2013, Pengaruh Musik pada Range Frekuensi (3000-6000) Hz terhadap Pertumbuhan dan Produktivitas Sawi Hijau (Brassica juncea), Skripsi, Universitas Kristen Satya Wacana, Jawa Tengah

Utami, S, Mayta, N \& Dyah, I, 2012, Aplikasi Musik Klasik, Pop Dan Hard Rock Terhadap Pertumbuhan Vegetatif Tanaman Cabai Merah Keriting (Capsicum annuum Var. Longum (Dc.) Sendtn), Skripsi, Fakultas Matematika dan Ilmu Pengetahuan Alam Universitas Riau, Riau

Utami, SS \& Agus, P, 2013, Pengaruh Pemaparan Suara Belalang "Kecek" (Orthoptera) Termanipulasi Pada Peak Frequency $3000 \mathrm{~Hz}$ Terhadap Pertumbuhan Tanaman Jati (Tectona grandis, L.F), Skripsi, Universitas Negeri Yogyakarta, Yogyakarta 